\title{
Sistem Pendeteksi Polusi Udara di Kota Bandar Lampung Menggunakan Teknologi Internet of Things (IoT)
}

\author{
${ }^{1}$ Muhammad Iqbal, ${ }^{2}$ Bambang Hermanto, ${ }^{3}$ Febi Eka Febriansyah, ${ }^{4}$ Muhammad Ridho \\ 1234 Jurusan Ilmu Komputer, Falkutas Matematika Ilmu Pengetahuan Alam, \\ Universitas Lampung, Bandar Lampung, 35141 \\ ${ }^{* 1}$ muhammadiqbal@fmipa.unila.ac.id
}

\begin{abstract}
Bandar Lampung City is the centre of the economy, services and trade in Lampung Province so that a healthy city environment needs to be kept clean and comfortable to support people's lives in carrying out daily activities. One factor that affects the cleanliness and comfort of the city of Bandar Lampung is the condition of air quality in the city of Bandar Lampung. The number of vehicles and industrial factories in the city of Bandar Lampung has become a major factor affecting air quality, such as the increase in harmful pollutant gases such as carbon monoxide gas (CO) and carbon dioxide (CO2), dust (PM10), nitrogen dioxide gas (NO2) and sulfur dioxide gas (SO2).Pollutant gas monitoring is one of the solutions in creating good air quality for the community. One of them is by utilizing information and communication technology. One of the utiliparameterion of information and communication technology in air quality monitoring is to use Wireless Sensor Network (WSN). WSN technology, which is the technology used to distribute and acquire data that is monitored and controlled centrally. This research builds an air pollution monitoring system in Bandar Lamping City by utilizing WSN and GSM technology for wireless data transmission to server applications. The results of this study are air pollution monitoring systems running well by displaying the outputs of sensor node acquisition based on the parameters of carbon monoxide (CO), dust (PM10), nitrogen dioxide (NO2) and sulfur dioxide (SO2) gases. The results of the calculation of the average overall sensor nodes for each parameter are $49 \mu \mathrm{g} / \mathrm{m} 3$ for PM10 substances, $34 \mu \mathrm{g} / \mathrm{m} 3$ for SO2 substances, 24 $\mu \mathrm{g} / \mathrm{m} 3$ for NO2 substances, and $25 \mu \mathrm{g} / \mathrm{m} 3$ for CO substances. Based on the ISPU index and category, the results are in a good category. This means that the condition of air quality in the city of Bandar Lampung in the good category.
\end{abstract}

Keywords: Air Pollution, ISPU, IoT, WSN, Bandarlampung.

\section{PENDAHULUAN}

Kota Bandar Lampung merupakan ibukota Provinsi Lampung sekaligus kota terbesar dan terpadat ketiga di Sumatera setelah Medan dan Palembang berdasarkan jumlah penduduk. Kota Bandar Lampng juga merupakan gerbang utama menuju pulau Sumatera serta merupakan jalur transportasi darat yang menghubungkan Pulau Jawa dan Pulau Sumatera.

Kota Bandar Lampung merupakan pusat perekonomian, jasa, serta perdagangan di Provinsi Lampung sehingga lingkungan kota yang sehat perlu dijaga kebersihan serta kenyamanannya untuk mendukung kehidupan masyarakat dalam melakukan aktifitas sehari-hari. Salah satu faktor yang memengaruhi kebersihan dan kenyamanan kota Bandar Lampung adalah kondisi kualitas udara di kota Bandar Lampung. Banyaknya kendaraan dan pabrik-pabrik industri di Kota Bandar Lampung menjadi faktor utama yang memengaruhi kualitas udara, seperti meningkatnya gas polutan berbahaya seperti gas karbon monoksida (CO) dan karbon dioksida (CO2), debu (PM10), gas nitrogen dioksida (NO2) dan gas sulfur dioksida ( $\mathrm{SO} 2)$.

Pemantauan gas polutan merupakan salah satu solusi dalam menciptakan kualitas udara yang baik bagi masyarakat. Salah satunya dengan memanfaatkan teknologi informasi dan komunikasi. Salah satu pemanfaatan teknologi informasi dan komunikasi dalam pemantauan kualitas udara yaitu dengan menggunakan Wireless Sensor Network (WSN). Teknologi WSN yang yaitu teknologi yang digunakan untuk mendistibusikan serta mengakuisisi data yang dipantau dan dikendalikan secara terpusat [1]. WSN 
sangat cocok diaplikasikan di wilayah geografis yang luas atau wilayah dengan kondisi berbahaya karena orang tidak bisa memantau kondisi wilayah tersebut setiap saat [2].

Penelitian tentang pemantauan polusi udara dengan menggunakan teknologi jaringan sensor nirkabel telah banyak dilakukan, diantaranya Iqbal, $M$ et al. (2015) yaitu WSN dengan topologi Hybrid Mesh-Like Tree dengan aplikasi berbasis web untuk sistem monitoring polusi udara berhasil menampilkan informasi tentang level pencemaran udara di kampus IPB Dramaga [3], Fuad, M et al (2015) membangun sistem pemantauan polusi udara gas CO di Kampus IPB Dramaga berbasiskan jaringan WSN dengan topologi mesh dengan protokol zigbee secara real time dan pengelolaan data dilakukan melalui aplikasi antar muka berbasis web [4]. Aziz et al (2012) yaitu sistem akuisisi data berbasis jaringan sensor nirkabel dengan protokol zigbee/IEEE 802.15.4 dan internet access pada sensor kristal fotonik untuk pengukuran indeks standar pencemar udara (ISPU) yang terintegrasi sehingga mampu memberikan informasi mengenai ISPU secara real time dan non-real time. Indeks Standar Pencemar Udara (ISPU) ditetapkan berdasarkan lima parameter utama yaitu: $\mathrm{CO}, \mathrm{CO} 2, \mathrm{SO} 2, \mathrm{NO} 2, \mathrm{O} 3$ dan partikel debu (PM-10) [5]. Penelitian selanjutnya oleh Roy, S, dan Bandyopadhyay, S. (2009) yang membangun sistem pemantauan polusi berbasiskan jaringan mesh nirkabel dengan protokol zigbee secara real time dan pengelolaan data dilakukan melalui aplikasi antar muka berbasis web [6]. Kemudian penelitian tentang sistem rumah pintar berbasis jaringan sensor nirkabel dengan teknologi zigbee dan GSM oleh Xu, M et al. (2010) dimana sistem ini menggunakan topologi hybrid star-mesh dan algoritma Dijkstra digunakan untuk routing yang mendukung komunikasi multi-hop [7].

Berdasarkan penelitian sebelumnya maka dalam penelitian ini akan membangun sistem pemantauan polusi udara di Kota Bandar Lamping dengan memanfaatkan teknologi WSN dan GSM untuk transmisi data secara nirkabel ke aplikasi server. Teknologi GSM digunakan sebagai perangkat transmisi data di daerah yang lebih luas dan cara mudah untuk mengakses internet [8].

\section{METODE PENGEMBANGAN SISTEM}

Penelitian ini dilakukan di laboratorium Komputasi Jurusan Ilmu Komputer Universitas Lampung. Pengujian sistem dilakukan di Kota Bandar Lampung.

Langkah-langkah pelaksanaan penelitian ini dibagi dalam beberapa tahapan, yaitu studi literatur, analisis permasalahan, perancangan model sistem, implementasi sistem analisis kinerja sistem. Langkahlangkah ini diilustrasikan pada Gambar 1.

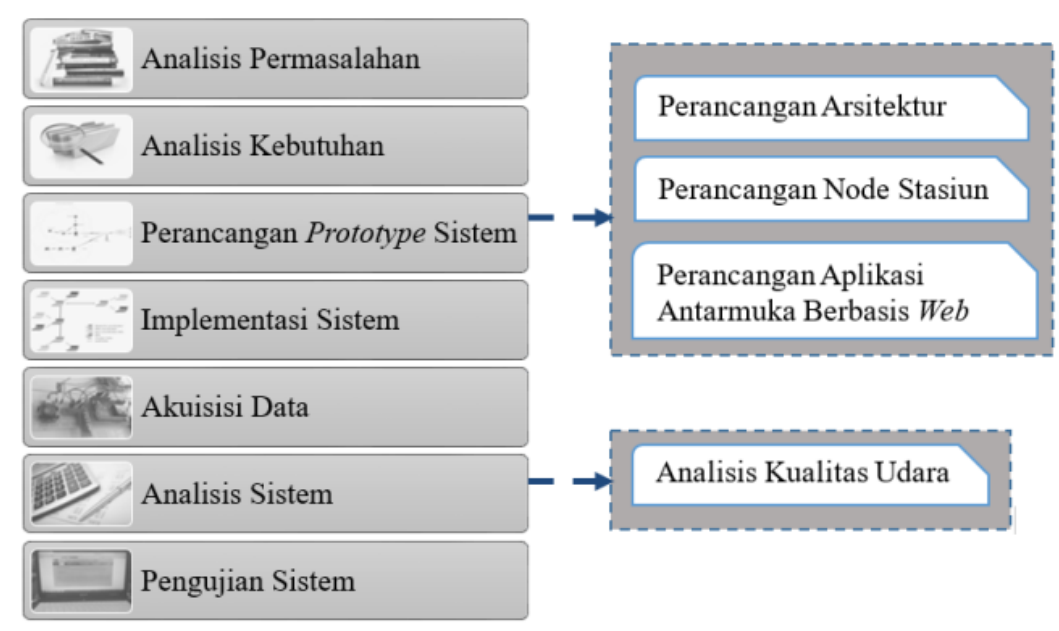

Gambar 1. Tahapan penelitian

Penjelasan dari tahapan peneitian ini sebagai berikut: 


\section{Analisis permasalahan}

Pada tahap ini dilakukan analisis permasalahan dengan mengumpulkan data dan metode yang tepat dengan melakukan studi pustaka, dokumentasi, dan observasi.

\section{Analisis kebutuhan}

Pada tahap ini dilakukan analisis kebutuhan penelitian seperti alat dan bahan sebagai pendukung penelitian. Alat dan bahan yang digunakan seperti perangkat keras Mikrokontroler Arduino, Sensor, Modul GSM dan perangkat lunak IDE Arduino, X-CTU, Framework Laravel, dan DBMS MySQL.

\section{Perancangan prototype system}

\section{a. Perancangan Arsitektur}

Perancangan ini terdiri dari perancangan prototype node sensor yang akan dikirimkan ke server menggunakan teknologi GSM. Data hasil akuisisi kemudian akan ditampilkan menggunakan antarmuka aplikasi web. Rancangan arsitektur sistem dapat dilihat pada Gambar 2.

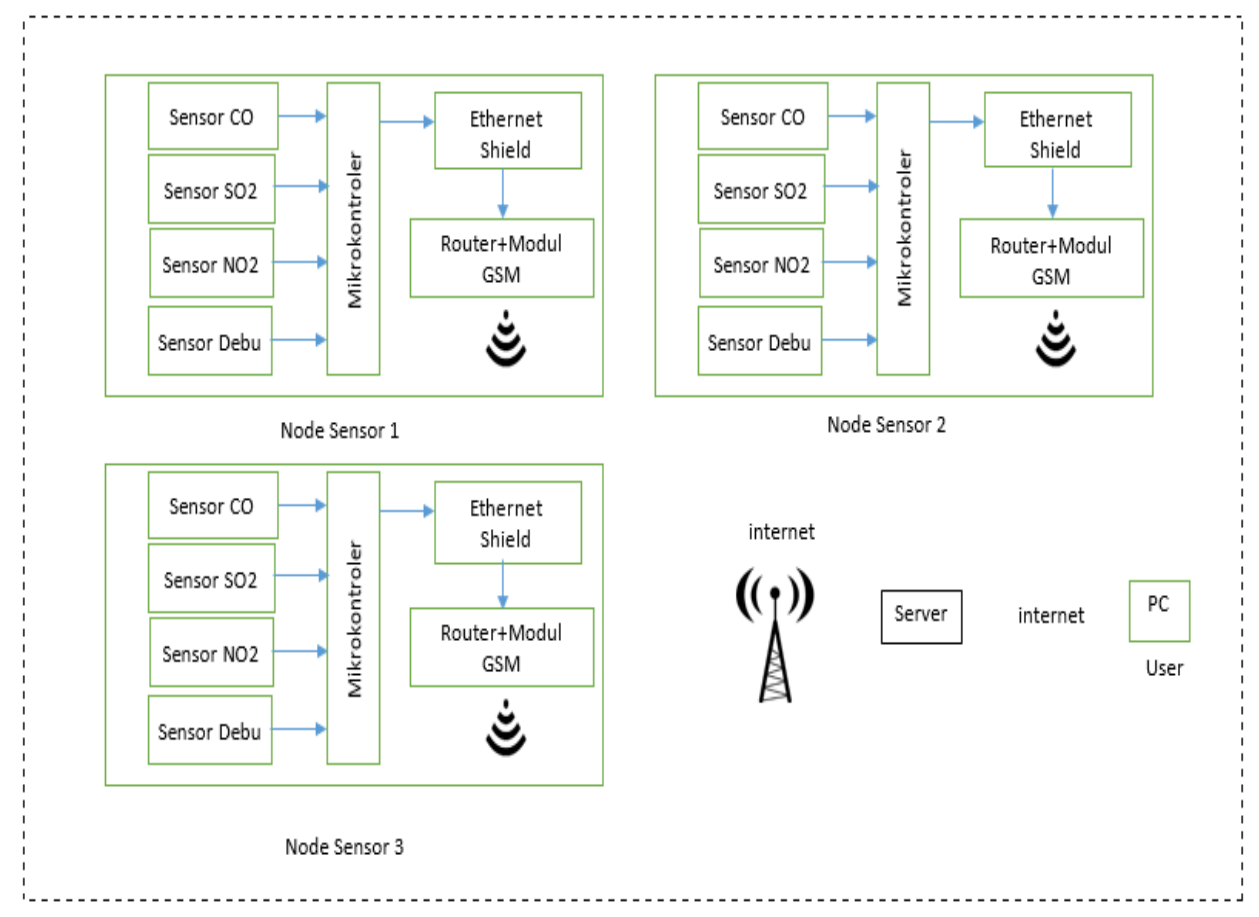

Gambar 2. Arsitektur Sistem

\section{b. Perancangan Node Sensor}

Perancangan ini terdiri dari perancangan node yang tersusun dari sensor, mikrokontroler, dan modem GSM. Sensor yang digunakan terdiri dari sensor $\mathrm{CO}$, Sensor $\mathrm{CO}$ 2, sensor NO2, sensor $\mathrm{SO}$ 2, dan sensor debu (PM10). Selain sensor yang digunakan, terdapat pula mikrokontroler arduino, sebagai server bagi masing-masing node, serta modul GSM untuk mengirimkan data ke server utama. Pada perancangan ini akan dibangun node sensor sebanyak 3 buah. Rancangan node dapat dilihat pada Gambar 3 . 
Vol 7 No. 2 , 2019

(C2019 Ilmu Komputer Unila Publishing Network all rights reserved

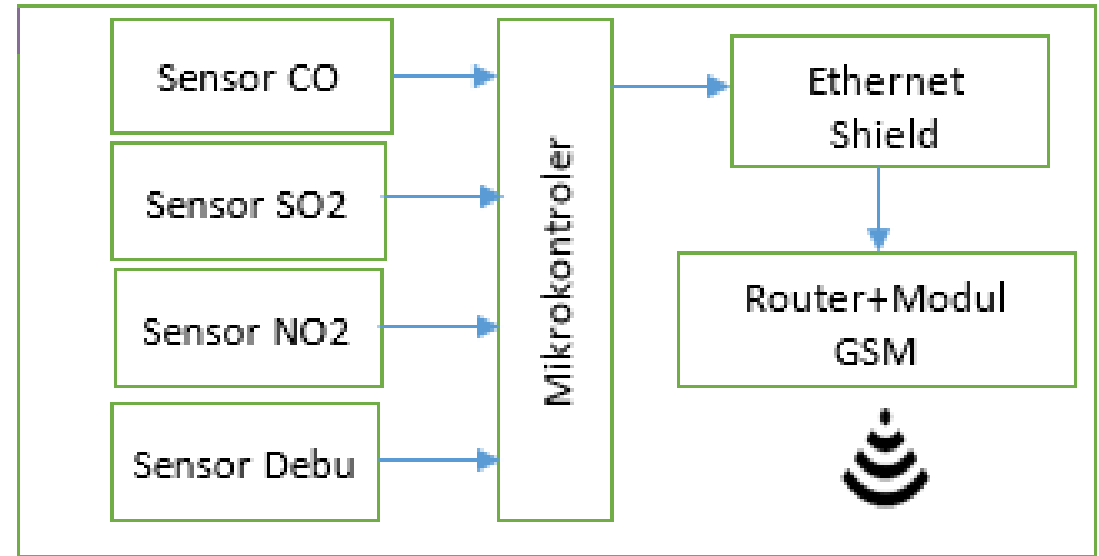

Gambar 3. Rancangan Node Sensor

\section{Perancangan aplikasi berbasis web}

Perancangan ini terdiri dari perancangan aplikasi berbasis web sebagai antarmuka pengguna untuk menampilkan informasi kualitas udara di Kota Bandar Lampung. Pada penelitian ini mengunakan framework Laravel dan DBMS MySQL. Berikut rancangan aplikasi antarmuka berbasis web dapat di lihat pada Gambar 4.

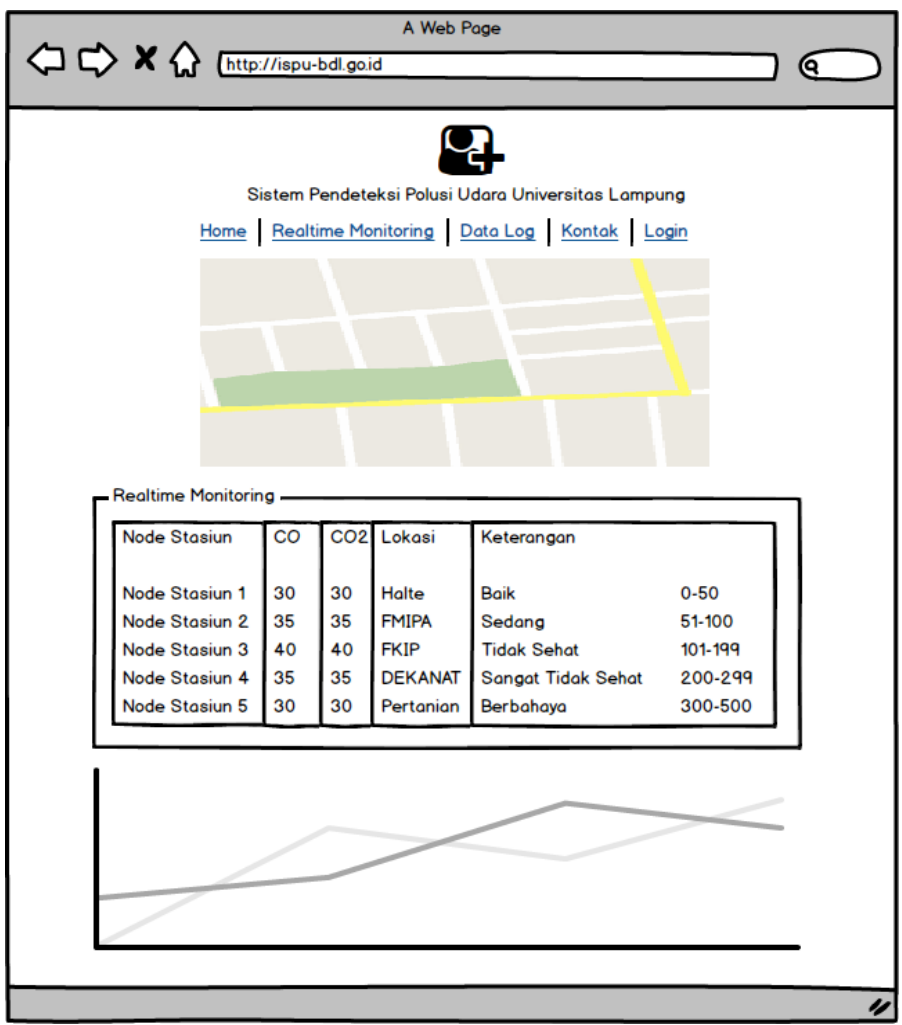

Gambar 4. Perancangan aplikasi antarmuka berbasis web

\section{Implementasi sistem}


Pada tahap ini dilakukan implementasi sistem sebelum dilakukan implementasi di Kota Bandar Lampung. Implementasi di lakukan di Laboratorium Kumputasi Dasar Ilmu Komputer FMIPA Universitas Lampung.

\section{Akuisisi data}

Pada tahap ini dilakukan akuisisi data di lapangan yaitu di Kota Bandar Lampung. Proses akuisisi data dilakukan selama 1 hari mulai pukul 7.30 sampai dengan 17.00 WIB. Jumlah data yang akuisisi sebanyak 1500 data.

\section{Analisis sistem}

Pada tahap ini dilakukan pengolahan data dan di analisis sesuai perhitungan nilai ISPU.

\section{Pengujian sistem}

Setelah semua tahap selesai maka tahap selanjutnya pengujian sistem. Tahap ini dilakukan dengan menjalankan semua bagian sistem dengan mengamati perubahan data yang ada di aplikasi berbasis web.

\section{PEMBAHASAN}

\subsection{Implementasi sistem}

Berikut rangkaian Node Sensor yang telah dirangkai dari komponen yang dibutuhkan untuk membangun sistem pemantauan polusi udara di Bandar Lampung. Rangkaian Node Sensor dapat dilihat pada Gambar 5.

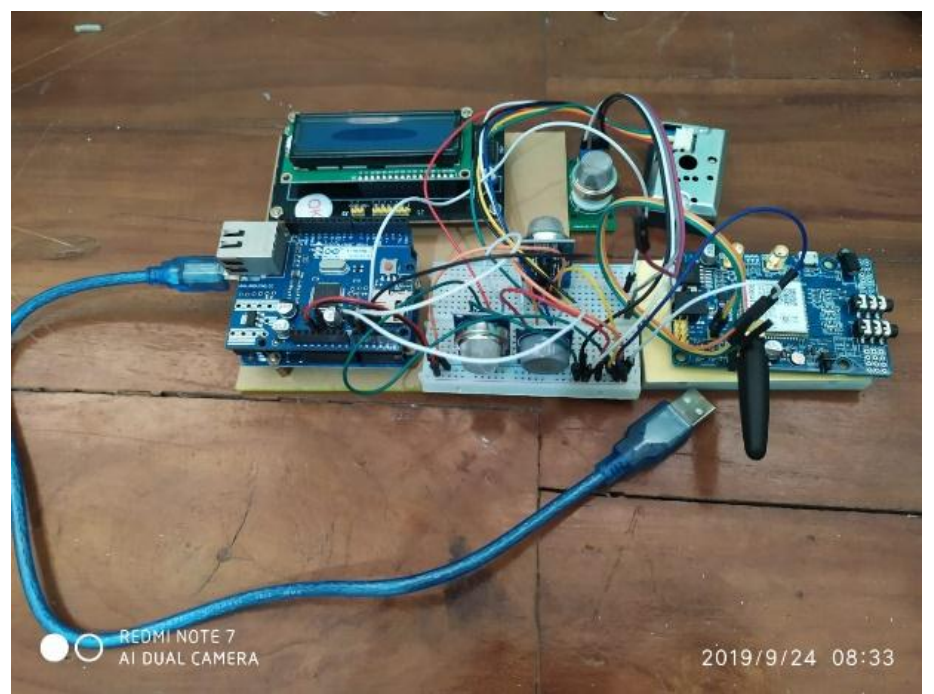

Gambar 5. Rangkaian Node Sensor

Komponen yang digunakan dalam sistem antara lain:

1. Mikrokontroler Arduino Uno,

2. Modul GSM SIM808,

3. LCD,

4. Sensor MQ2,

5. Sensor MQ9,

6. Sensor MQ135,

7. Sensor MQ136 dan

8. Sensor Dust Sensor SHARP GP2Y1014AU0F 


\subsection{Akuisisi data}

Hasil akuisisi data dilapangan berfungsi dengan baik. Perangkat node sensor berhasil mengakusisi data berdasarkan parameter sensor yang digunakan. Sampel data yang telah diakuisisi dapat dilihat pada Tabel 2.

Tabel 2. Sampel Hasil Akuisisi Data dari Node Sensor

\begin{tabular}{ccccc}
\hline Node & $\mathrm{PM} 10$ & $\mathrm{SO}_{2}$ & $\mathrm{NO}_{2}$ & $\mathrm{CO}$ \\
\hline 1 & 16 & 31 & 17 & 14 \\
1 & 16 & 31 & 17 & 14 \\
1 & 16 & 31 & 17 & 14 \\
1 & 16 & 31 & 17 & 14 \\
1 & 16 & 30 & 17 & 14 \\
1 & 16 & 31 & 18 & 14 \\
1 & 16 & 31 & 18 & 15 \\
1 & 16 & 30 & 17 & 14 \\
1 & 16 & 30 & 17 & 14 \\
1 & 16 & 30 & 17 & 14 \\
2 & 88 & 52 & 40 & 41 \\
2 & 88 & 52 & 40 & 41 \\
2 & 88 & 52 & 40 & 41 \\
2 & 87 & 52 & 40 & 41 \\
2 & 87 & 52 & 39 & 41 \\
2 & 87 & 51 & 39 & 41 \\
2 & 87 & 51 & 39 & 41 \\
2 & 88 & 52 & 40 & 41 \\
2 & 88 & 52 & 40 & 41 \\
2 & 87 & 52 & 40 & 41 \\
3 & 50 & 26 & 21 & 26 \\
3 & 50 & 26 & 21 & 26 \\
3 & 50 & 26 & 21 & 26 \\
3 & 50 & 26 & 21 & 26 \\
3 & 50 & 26 & 21 & 26 \\
3 & 50 & 26 & 21 & 26 \\
3 & 50 & 26 & 21 & 26 \\
3 & 50 & 26 & 21 & 26 \\
3 & 50 & 26 & 21 & 26 \\
3 & 50 & 26 & 21 & 26 \\
\hline & & & &
\end{tabular}

\subsection{Analisis sistem}

Berdasarkan hasil akuisisi data perangkat node sensor yang digunakan, didapat hasil analisis kualitas udara untuk masing-masing node. Hasil analisis node sensor 1 dapat dilihat pada Tabel 3. Hasil analisis node sensor 2 dapat dilihat pada Tabel 4. Hasil analisis node sensor dapat dilihat pada Tabel 5. Utuk hasil analisis keseluruhan dapat dilihat pada Tabel 6.

Tabel 3. Hasil Analisis Node sensor 1 
Vol 7 No. 2 , 2019

(C)2019 Ilmu Komputer Unila Publishing Network all rights reserved

\begin{tabular}{lcc}
\hline Parameter & Hasil & Keterangan \\
\hline PM10 & 15 & Sedang \\
SO$_{2}$ & 28 & Baik \\
$\mathbf{N O}_{2}$ & 15 & Baik \\
$\mathbf{C O}$ & 12 & Baik \\
\hline
\end{tabular}

Tabel 4. Hasil Analisis Node Sensor 2

\begin{tabular}{lcc}
\hline Parameter & Hasil & Keterangan \\
\hline PM10 & 84 & Sedang \\
SO$_{2}$ & 49 & Baik \\
$\mathbf{N O}_{2}$ & 37 & Baik \\
$\mathbf{C O}$ & 39 & Baik \\
\hline
\end{tabular}

Tabel 5. Hasil Analisis Node Sensor 3

\begin{tabular}{lcc}
\hline Parameter & Hasil & Keterangan \\
\hline PM10 & 47 & Baik \\
SO$_{2}$ & 24 & Baik \\
$\mathbf{N O}_{2}$ & 19 & Baik \\
CO & 25 & Baik \\
\hline
\end{tabular}

Tabel 6. Hasil rata-rata analisis Node Sensor Keseluruhan

\begin{tabular}{lcc}
\hline Parameter & Hasil & Keterangan \\
\hline PM10 & 49 & Baik \\
SO$_{2}$ & 34 & Baik \\
$\mathbf{N O}_{2}$ & 24 & Baik \\
$\mathbf{C O}$ & 25 & Baik \\
\hline
\end{tabular}

\subsection{Pengujian sistem}

Hasil pengujian sistem menunjukkan bahwa sistem telah berhasil menampilkan output hasil akuisisi sensor ke aplikasi web berdasarkan parameter sensor yang digunakan. Pada tampilan web terdapat 3 menu yaitu Beranda, Statistik dan Data Log. Gambar 6 menunjukkan halaman utama sistem (Beranda). Pada halaman tersebut terdapat grafik batang yang menunjukkan data yang terakhir diambil oleh sensor serta informasi nilai dari masing-masing node sensor yang dapat dilihat pada Gambar 7. Gambar 8, 9 dan 10 menunjukkan tampilan antarmuka Statistik yang berisi informasi grafik dari masing-masing Node Sensor. Gambar 11 menunjukkan tampilan antarmuka halaman Data Log yang berisi Tabel dari seluruh data yang dikirimkan oleh Node Sensor. 
Vol 7 No. 2 , 2019

○2019 Ilmu Komputer Unila Publishing Network all rights reserved

Jurnal Komputasi

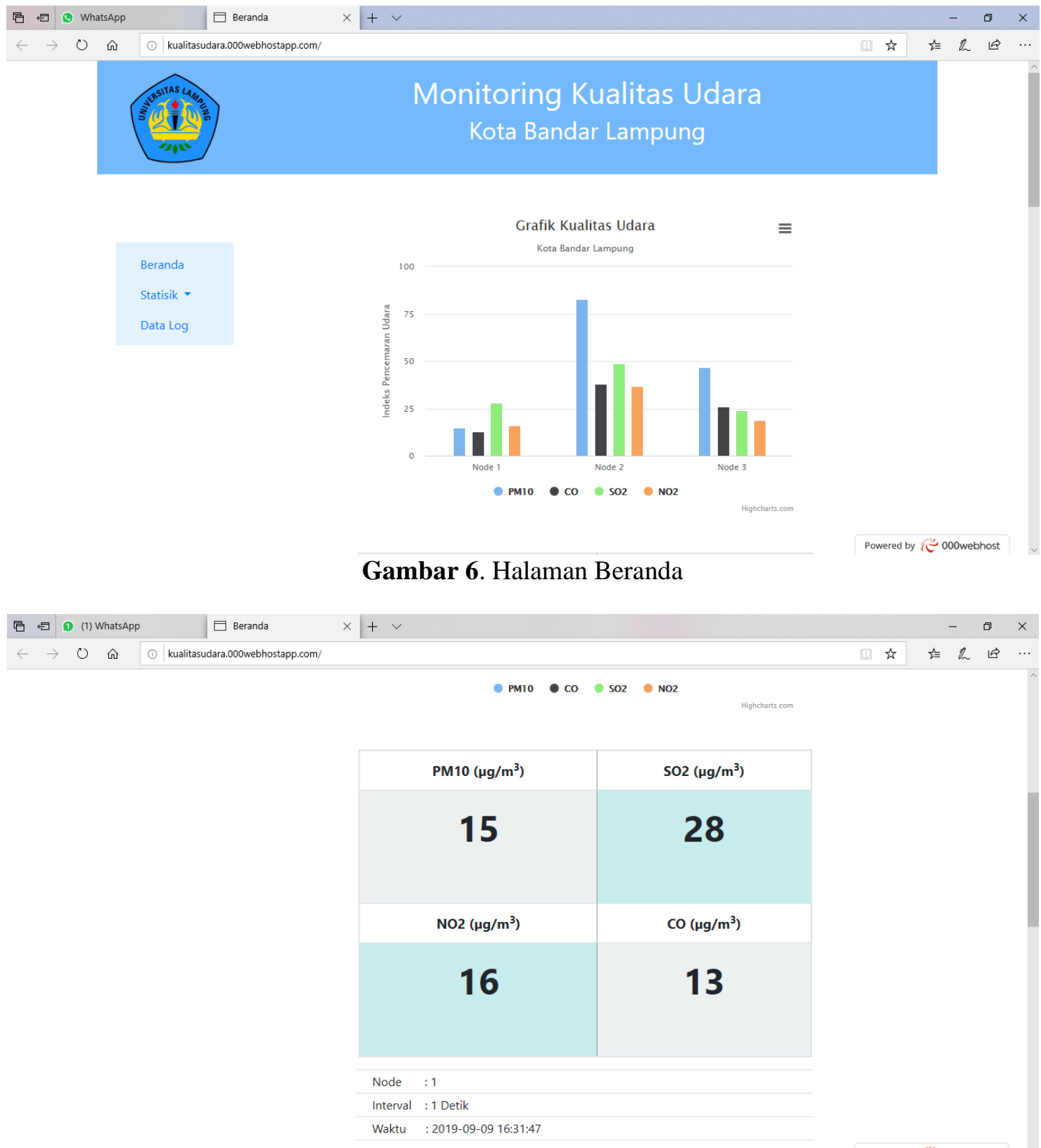

Gambar 7. Informasi Nilai Sensor 
Vol 7 No. 2 , 2019

O2019 Ilmu Komputer Unila Publishing Network all rights reserved

Jurnal Komputasi

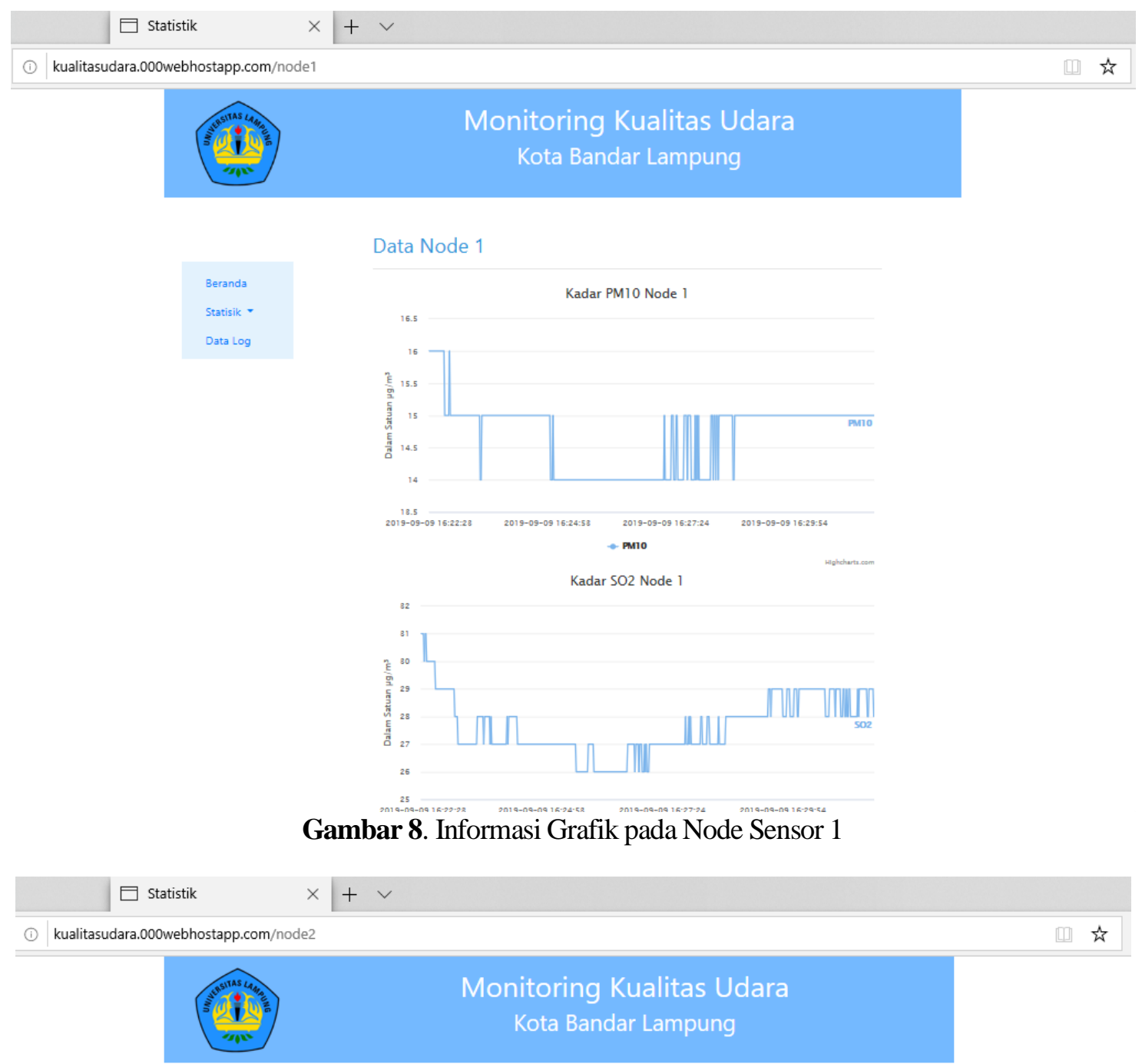

Data Node 2

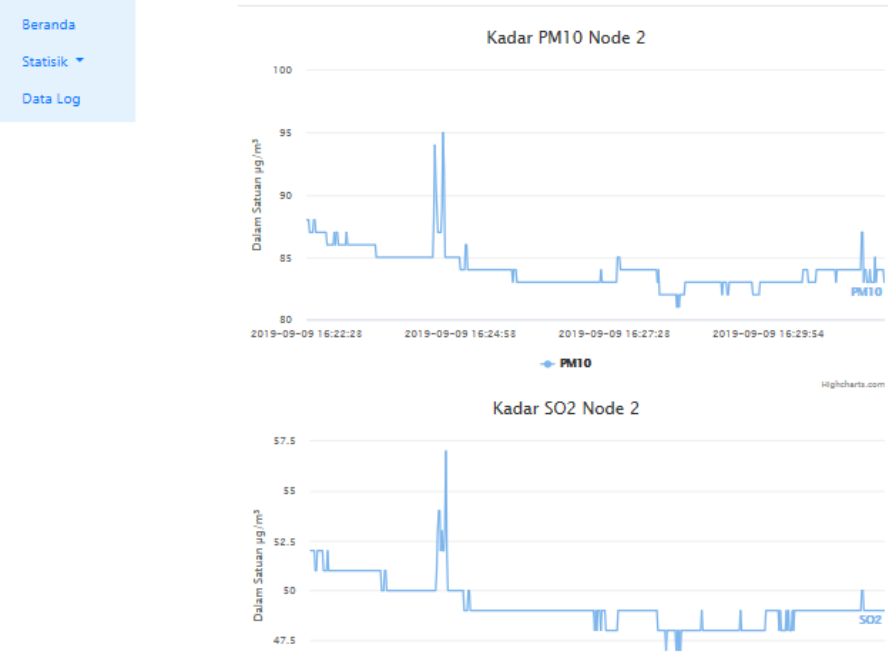

Gambar 9. Informasi Grafik pada Node Sensor 2 
Vol 7 No. 2 , 2019

O2019 Ilmu Komputer Unila Publishing Network all rights reserved

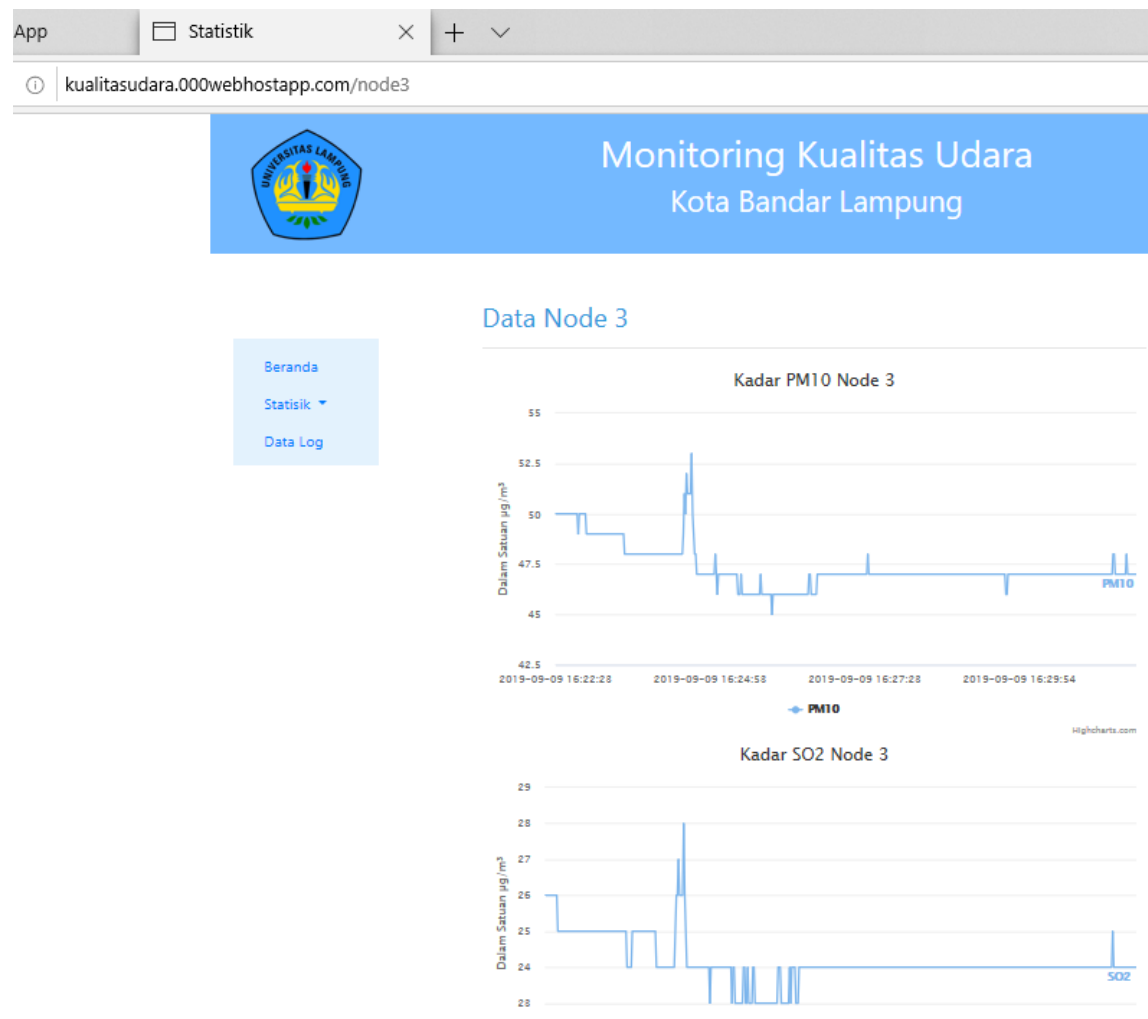

Gambar 10. Informasi Grafik pada Node Sensor 3

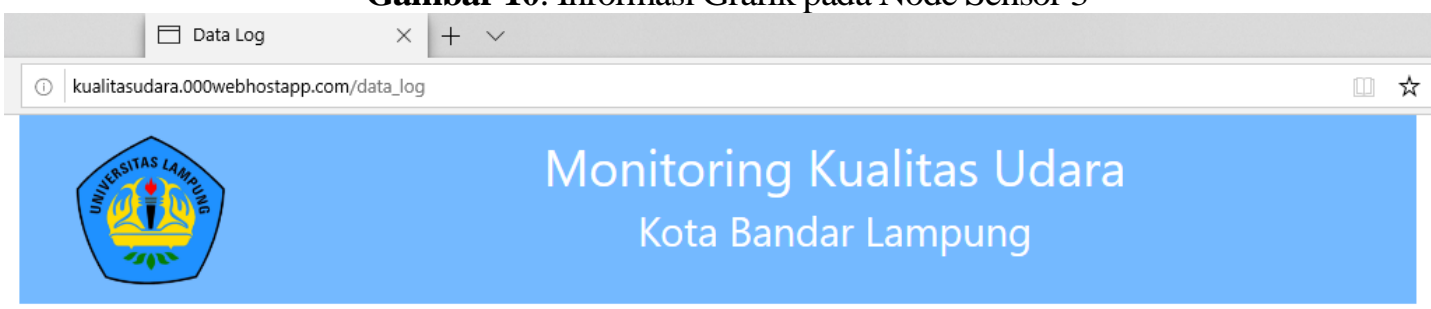

Data Log Polusi Udara

Beranda

Statisik -

Data Log
Halaman $\quad: 1$

Jumlah Data $\quad: 1692$

Data Per Halaman : 300

\begin{tabular}{cccccc} 
Node & PM10 & SO2 & NO2 & CO & Waktu \\
\hline 1 & 16 & 31 & 17 & 14 & 2019-09-09 16:22:23 \\
\hline 1 & 16 & 31 & 17 & 14 & 2019-09-09 16:22:24 \\
\hline 1 & 16 & 31 & 17 & 14 & $2019-09-09$ 16:22:25 \\
\hline 1 & 16 & 31 & 17 & 14 & $2019-09-0916: 22: 26$ \\
\hline 1 & 16 & 30 & 17 & 14 & $2019-09-0916: 22: 27$ \\
\hline 1 & 16 & 31 & 18 & 14 & $2019-09-0916: 22: 28$ \\
\hline 1 & 16 & 31 & 18 & 15 & $2019-09-09$ 16:22:29 \\
\hline 1 & 16 & 30 & 17 & 14 & $2019-09-09$ 16:22:30
\end{tabular}

Gambar 11. Data log Node Sensor 


\section{KESIMPULAN}

Berdasarkan hasil penelitian dapat disimpulkan sebagai berikut:

1. Sistem monitoring polusi udara berjalan dengan baik dengan menampilkan output hasil akuisisi node sensor berdasarkan parameter sensor.

2. Berdasarkan data yang di akuisisi oleh node sensor dapat ditarik kesimpulan sebagai berikut:

a. Rata-rata hasil perhitungan ISPU parameter PM10 adalah $15 \mu \mathrm{g} / \mathrm{m}^{3}$ pada node sensor 1,84 $\mu \mathrm{g} / \mathrm{m}^{3}$ pada node sensor 2 dan $47 \mu \mathrm{g} / \mathrm{m}^{3}$ pada node sensor 3 .

b. Rata-rata hasil perhitungan ISPU parameter $\mathrm{SO}_{2}$ adalah $28 \mu \mathrm{g} / \mathrm{m}^{3}$ pada node sensor $1,49 \mu \mathrm{g} / \mathrm{m}^{3}$ pada node sensor 2 , dan $24 \mu \mathrm{g} / \mathrm{m}^{3}$ pada node sensor 3 .

c. Rata-rata hasil perhitungan ISPU parameter $\mathrm{NO}_{2}$ adalah $15 \mu \mathrm{g} / \mathrm{m}^{3}$ pada node sensor 1,37 $\mu \mathrm{g} / \mathrm{m}^{3}$ pada node sensor 2 , dan $19 \mu \mathrm{g} / \mathrm{m}^{3}$ pada node sensor 3 .

d. Rata-rata hasil perhitungan ISPU parameter CO adalah $12 \mu \mathrm{g} / \mathrm{m}^{3}$ pada node sensor $1,39 \mu \mathrm{g} / \mathrm{m}^{3}$ pada node sensor 2 , dan $25 \mu \mathrm{g} / \mathrm{m}^{3}$ pada node sensor 3 .

e. Rata-rata hasil perhitungan keseluruhan node sensor untuk masing-masing parameter adalah $49 \mu \mathrm{g} / \mathrm{m}^{3}$ untuk parameter PM 10, $34 \mu \mathrm{g} / \mathrm{m}^{3}$ untuk parameter $\mathrm{SO}_{2}, 24 \mu \mathrm{g} / \mathrm{m}^{3}$ untuk parameter $\mathrm{NO}_{2}$, dan $25 \mu \mathrm{g} / \mathrm{m}^{3}$ untuk parameter $\mathrm{CO}$.

\section{UCAPAN TERIMAKASIH}

Terima kasih kepada LPPM Universitas Lampung yang telah mendanai penelitian ini untuk Program Penelitian Dosen Pemula (PDP) Tahun 2019.

\section{DAFTAR PUSTAKA}

[1] F. L. Lewis. 2004. Jaringan sensor nirkabels. Smart Environments: Technologies, Protocols, and Applications ed. D.J. Cook and S.K. Das, John Wiley, New York

[2] Mainwaring, A et al. 2002. Jaringan sensor nirkabels for habitat monitoring. In Proceedings of ACM International Workshop on Jaringan sensor nirkabels and Applications, Atlanta, GA, USA, 28 September 2002; pp.88-97A.

[3] Iqbal, M., Sukoco, H., \& Alatas, H. 2015. Design Wireless Sensor Network based on Hybrid MeshLike Tree Topology for Air Pollution Monitoring System. Telkomnika

[4] Fuad, M., Iqbal, M., Rahmat, M., Sukoco, H., \& Alatas, H. (2015). Performance Analysis of ZigBee Mesh WSN in Carbon Monoxide Gas Monitoring System. TELKOMNIKA Indonesian Journal of Electrical Engineering, 15(3), 576-583.

[5] Aziz M et al. 2011. Measuring Air Pollutants Standard Index (ISPU) with Photonics Crystal Sensor based on Jaringan sensor nirkabel (WSN). International Conference on Instrumentation, Communication, Information Technology and Biomedical Engineering 8-9 November 2011, Bandung, Indonesia

[6] Roy, S., \& Bandyopadhyay, S. (2009). Testbed implementation of a pollution monitoring system using wireless sensor network for the protection of public spaces. International Journal of Business Data Communications and Networking (IJBDCN), 5(4), 16-32.

[7] Xu, M., Ma, L., Xia, F., Yuan, T., Qian, J., \& Shao, M. (2010, October). Design and implementation of a wireless sensor network for smart homes. InUbiquitous Intelligence \& Computing and 7th International Conference on Autonomic \& Trusted Computing (UIC/ATC), 2010 7th International Conference on (pp. 239-243). IEEE.

[8] Lin, S., \& Ming, L. (2008). A wireless network based on the combination of Zigbee and GPRS. In Networking, Sensing and Control, 2008. ICNSC 2008. IEEE International Conference on (pp. 267-270). IEEE. 